\title{
2020 Editor's Choice Award and Editor's Choice Articles
}

\author{
Kensuke Nakata ${ }^{1}$
}

Accepted: 27 November 2020 / Published online: 5 January 2021

(C) Japan Ethological Society 2021

The editorial committee of the Journal of Ethology awards a prize for the best paper published in the journal, the Editor's Choice Award, every year. In addition, the committee selects certain outstanding papers as Editor's Choice articles. I am very pleased to announce the award winner and the list of the Editor's Choice articles for 2020.

\section{Editor's Choice Award}

Yuto Hikidi et al. (2020). An elaborate behavioural sequence reinforces the decoy effect of ink during predatory attacks on squid (Volume 38, Issue 2, pp 155-160).

The authors demonstrate the function of the inking behaviour of the Japanese pygmy squid by combining field observations and laboratory experiments. The editorial committee highly commended the paper, since it seeks to confirm the detailed sequences involved in inking behaviour, which suggest the cognitive complexity of squid and fishes. The committee also noted that the paper provides impressive videos of squid behaviour in the field, which are valuable resources.

\section{Editor's Choice Articles}

Shumpei Hisamoto et al. (2020). Route reassessment by transporter ants improves speed and directional accuracy of cooperative transport in Formica japonica (Volume 38, Issue 1, pp 107-116).

Monamie Ringhofer et al. (2020). Herding mechanisms to maintain the cohesion of a harem group: two interaction phases during herding (Volume 38, Issue 1, pp 71-77).

Juan C. F. Pardo et al. (2020). Fiddler crabs and their above-ground sedimentary structures: a review (Volume 38, Issue 2, pp 137-154).

Kensuke Nakata

nakatake@kyoto-wu.ac.jp

1 Kyoto Women's University, Kyoto, Japan
Masaru Hasegawa et al. (2020). Experimental tail shortening affects feeding rate depending on original tail length in female barn swallows Hirundo rustica gutturalis (Volume 38, Issue 2, pp 179-184).

Ximena J. Nelson et al. (2020). Widespread army ant aversion among East African jumping spiders (Salticidae) (Volume 38, Issue 2, pp 185-194).

Vladislav Marcuk et al. (2020). Qualitative description of the submission and agonistic behavior of the Spix's Macaw (Cyanopsitta spixii, Spix 1824) (Volume 38, Issue 2, pp 253-270).

\section{References}

Hasegawa M, Arai E, Nakamura M (2020) Experimental tail shortening affects feeding rate depending on original tail length in female barn swallows Hirundo rustica gutturalis. J Ethol 38:179-184

Hikidi Y, Hirohashi N, Kasugai T, Sato N (2020) An elaborate behavioural sequence reinforces the decoy effect of ink during predatory attacks on squid. J Ethol 38:155-160

Hisamoto S, Hosaka N, Matsunami Y, Iwasaki H (2020) Route reassessment by transporter ants improves speed and directional accuracy of cooperative transport in Formica japonica. J Ethol 38:107-116

Marcuk V, Purchase C, de Boer D, Bürkle M, Scholtyssek K (2020) Qualitative description of the submission and agonistic behavior of the Spix's Macaw (Cyanopsitta spixii, Spix 1824). J Ethol 38:253-270

Nelson XJ, Aguilar-Arguello S, Jackson RR (2020) Widespread army ant aversion among East African jumping spiders (Salticidae). J Ethol 38:185-194

Pardo JCF, Stefanelli-Silva G, Christy JH, Costa TM (2020) Fiddler crabs and their above-ground sedimentary structures: a review. J Ethol 38:137-154

Ringhofer M, Go CK, Inoue S, Mendonça RS, Hirata S, Kubo T, Ikeda K, Yamamoto S (2020) Herding mechanisms to maintain the cohesion of a harem group: two interaction phases during herding. J Ethol 38:71-77

Publisher's Note Springer Nature remains neutral with regard to jurisdictional claims in published maps and institutional affiliations. 